Contents lists available at \ournal IICET

JPPI (Jurnal Penelitian Pendidikan Indonesia)

ISSN: 2502-8103 (Print) ISSN: 2477-8524 (Electronic)

\title{
Evaluation of the implementation of the sekolah penggerak curriculum using the context, input, process and product evaluation model in high schools
}

\author{
Anggarda Paramita Muji ${ }^{\left.1^{*}\right)}$, Nurhizrah Gistituati ${ }^{2}$, Alwen Bentri ${ }^{2}$, Fris Okta Falma ${ }^{1}$ \\ ${ }^{1}$ Doctoral Program Student of Educational Sciences, Universitas Negeri Padang, Indonesia \\ ${ }^{2}$ Universitas Negeri Padang, Indonesia
}

\section{Article Info \\ Article history: \\ Received Aug $12^{\text {th }}, 2021$ \\ Revised Sept $10^{\text {th }}, 2021$ \\ Accepted Oct $27^{\text {th }}, 2021$}

\section{Keyword:}

Sekolah Penggerak

CIPP Evaluation Model

Learning evaluation

\begin{abstract}
Learning evaluation is to find out how far the progress, development, and success of students after carrying out the learning process within the specified time period is, including the evaluation of the innovative learning curriculum, namely the sekolah penggerak curriculum. The purpose of this study is to describe the evaluation of the school curriculum using the Context, Input, Process and Product (CIPP) evaluation model. Qualitative research designed in the form of case study research. The research subjects were the principal, curriculum representative, and school supervisor. Determination of research subjects was carried out purposively. Data collection techniques using observation sheets and data analysis techniques used are descriptive statistics. Research findings using the Context, Input, Process and Product (CIPP) is seen from the Context, Input, Process and Product aspects that the implementation of the sekolah penggerak curriculum is in accordance with the learning objectives. The implementation of this curriculum innovation is expected to have an impact on the quality of learning outcomes, the quality of the main competencies, the quality of teachers, the acceleration of school digitization and the profile of Pancasila students.
\end{abstract}

C 2021 The Authors. Published by IICET.

This is an open access article under the CC BY-NC-SA license (https://creativecommons.org/licenses/by-nc-sa/4.0)

\section{Corresponding Author:}

Anggarda Paramita Muji,

Doctoral Program Student of Educational Sciences, Universitas Negeri Padang

Email: anggardaparamitamuj@gmail.com

\section{Introduction}

Education is a means of forming and developing student knowledge so that a curriculum that is in accordance with learning objectives is needed (Sabri, 2017), because education is the foundation of knowledge for students (Ma'arif, 2018). In order to achieve optimal development of student potential, a curriculum is needed as a reference for educators in designing learning scenarios that are in accordance with what is used as the basis for developing student understanding and optimizing all student potential by designing learning that leads to the formation of students' attitudes, knowledge and psychomotor. In student-centered learning, understanding and creativity of teachers are needed in designing an innovative and fun learning strategy (Habibi et al., 2020).

Curriculum is used to identify educational plans for students, and what students are learning. The curriculum is a learning educational plan for students because the curriculum is the content of learning (Forey, \& Cheung, 2019). We need to understand that schools were established to guide students to develop in accordance with the expected goals. This means that the central point of the curriculum is the students 
themselves. Student development will only be achieved if he/she gains learning experience through all the activities presented by the school, both through subjects and other activities. Furthermore, the curriculum as a learning plan must lead to the acquisition of student experiences that are deliberately designed for them to have (Afdal, \& Spernes, 2018).

The curriculum used as a reference for education should need to be evaluated and continue to develop according to the needs of the community. In implementing the curriculum, we can observe and evaluate the implementation of a teaching and learning process (Maba, 2017). Evaluation aims to find out whether the teaching and learning process has achieved the goals that have been set or not, in other words the teaching and learning process is not yet known whether or not it is successful before the evaluation is carried out. So that evaluation must be needed in the teaching and learning process (Black, \& William, 2018). With a good and thorough evaluation, you will be able to find out what you want from teaching and learning activities. From a good evaluation, it will be able to motivate both students and teachers. In the science of educational evaluation, There are many models that can be used to evaluate a program. Although they differ from one another, the intent is the same, namely to collect data or information related to the object being evaluated, whose purpose is to provide material for decision makers and determine the follow-up of a program. One of the evaluation models that is quite commonly used is the evaluation model ( CIPP) Context, Input, Process and Product (Umam, \& Saripah, 2018; Aziz et al., 2018). This evaluation is also no exception to the implementation of the sekolah penggerak curriculum. This program exists in order to improve the quality of education, as a model for quality education units. The sekolah penggerak curriculum focuses on developing student learning outcomes holistically which includes literacy, numeracy and character competencies, starting with superior resources from principals and teachers (Wijaya, Mustofa, \& Husain, 2020). The sekolah penggerak curriculum is a program that focuses on improving student competencies holistically to further encourage the realization of the Pancasila student profile.

The sekolah penggerak curriculum is a refinement of the previous school transformation program. The sekolah penggerak curriculum is an effort to realize the vision of Indonesian Education in realizing an advanced Indonesia that is sovereign, independent, and has personality through the creation of Pancasila Students (Sibagariang, Sihotang, \& Murniarti, 2021). The Sekolah penggerak curriculum will accelerate public and private schools in all school conditions to move 1-2 stages further. The program is carried out in stages and is integrated with the ecosystem until all schools in Indonesia become the Sekolah penggerak Program. Evaluation model (CIPP) Context, Input, Process and Product used to evaluate the implementation of the sekolah penggerak, especially in high school learning.

\section{Method}

This research is a qualitative research designed in the form of case study research (Bhakti, 2017; Purnomo, \& Santoso, 2020). The research subjects were principals, curriculum representatives, and senior high school supervisors in Padang City, and described in a qualitative descriptive form. In this study, it is limited to a qualitative description of the implementation of the sekolah penggerak in terms of the Context, Input, Process and Product evaluation model (CIPP) in senior high schools in Padang City. Determination of research subjects was carried out purposively. Data collection techniques using observation sheets (Sulistyo, 2017). The data analysis technique used is descriptive statistics (Ahmad, \& Nasution, 2018). The evaluation procedure is carried out according to the principles of the Context, Input, Process and Product aspects as follows: 1) The context assessment includes school profile, school learning program background, geographic-demographic factors, and socioeconomic and educational background of the students' parents. The information collected is used as a basis for program considerations; 2) The input assessment includes students, curriculum, teaching materials, and teachers and learning facilities. The data collected during the assessment stage is used as a decision maker; 3) Process assessment is an assessment activity during the implementation of learning. This assessment is directly related to learning activities, use of learning media,utilization laboratories, and assigning types of assignments; 4) Product/output assessment, related to the results of program implementation. Assessment is carried out to find out how far the implementation of learning inimplication The sekolah penggerak curriculum in the classroom has succeeded in achieving the objectives based on the established criteria, which include student learning outcomes and average grades.

To facilitate the implementation of the evaluation, the following CIPP observation sheet for sekolah penggerak has been adjusted using the Context, Input, Process and Product evaluation model (Supriyantoko et al., 2020; Aziz et al., 2021), namely: 
Table 1. Observation Sheet Evaluation of the Implementation of the Sekolah penggerak Curriculum with the CIPP Model in Senior High Schools

\begin{tabular}{|c|c|c|c|c|c|}
\hline \multirow{2}{*}{$\begin{array}{c}\text { Sub } \\
\text { Variable }\end{array}$} & \multirow[t]{2}{*}{ Statement } & \multicolumn{4}{|c|}{ Answer } \\
\hline & & SB & B & CB & KB \\
\hline Context & 1. The suitability of the curriculum to the needs of students & & & & \\
\hline & 2. Conformity of curriculum with learning objectives & & & & \\
\hline & 3. The suitability of the curriculum with current developments & & & & \\
\hline & 4. Principal's understanding of the curriculum & & & & \\
\hline & 5. Teacher understanding of curriculum & & & & \\
\hline & 6. Ease of teachers in implementing the curriculum & & & & \\
\hline & 7. Student interest in learning with a driving curriculum & & & & \\
\hline & $\begin{array}{l}\text { 8. Providing socialization with all parties to the curriculum } \\
\text { (Parents, Teachers, Students) }\end{array}$ & & & & \\
\hline
\end{tabular}

Input 1. The suitability of the material presented with the principle of Pancasila values

2. Scope the material provided is in accordance with the lesson plan and the driving curriculum

3. Availability of facilities and infrastructure that supports the implementation of the driving curriculum in learning

4. The existence of an evaluation instrument or supervision from the principal to the implementation of the driving curriculum by teachers in learning

5. The role of the principal in improving the quality of educators in improving competence educator

6. The teacher's ability to implement the driving curriculum

7. Effective use of the driving curriculum for the learning process

8. The suitability of the learning strategy with the driving curriculum

Process 1. Understanding level student to learning given in accordance with the profile of Pancasila students

2. The teacher's ability to guide and direct students to the driving curriculum goals

3. Utilization of facilities and infrastructure that support the implementation of the driving curriculum in learning activities

4. The use of digital in the learning process

5. The ability of teachers to overcome obstacles that occur during the learning process

6. The existence of an assessment rubric or teacher assessment format in the evaluation of learning

7. Conformity between the learning strategy and the driving curriculum objectives

8. Availability of learning media from teachers to support the learning process

Product 1. The quality of expected learning outcomes is in accordance with the profile of Pancasila students

2. Suitability between learning objectives in the curriculum and student achievement

3. Match between results and student needs

4. The suitability of the schedule or time in the implementation of learning

5. Increasing students' abilities in knowledge and experience of the learning that has been given

6. Students understand the use of digital as a means of learning 
The assessment criteria become a reference in translating the meaning and evaluation results found in the field. In addition, it also functions as a differentiator for the level of achievement of each indicator. In this criterion using a Likert scale with SB code meaning very good, getting a value of 4 means that it is really in accordance with the reality in the field, then code B means good, getting a value of 3 means that it is in accordance with the reality in the field, then the $\mathrm{CB}$ code means quite good, getting a value of 2 means that it is not in accordance with the reality in the field, and finally the KB code means that it is not good, getting a value of 1 means that it is not in accordance with the reality in the field.

\section{Results and Discussions}

The issue of the challenges of globalization and the rush of digital information in the era of the industrial revolution 4.0 and society 5.0 demands very serious attention in education today (Fukuda, 2020; Hidayat et al., 2019a; 2019b), especially in preparing graduates who are competitive and qualified (Aquilani et al., 2020). Developing countries, including Indonesia, always think about and prepare quality graduates, especially in instilling the values of the nation's character (Dewantara et al., 2020). The curriculum innovation that is currently developing is the sekolah penggerak curriculum, namely with the concept of perfecting the previous school transformation program. The sekolah penggerak curriculum aims to: 1). improve competence and character in accordance with the profile of Pancasila students; 2). ensure equal distribution of education quality through capacity building programs for principals who are able to lead educational units in achieving quality learning; 3). build a stronger education ecosystem focused on improving quality; and 4). create a collaborative climate for stakeholders in the field of education both at the school, local government, and government scope.

Furthermore, to find out how successful the implementation of this sekolah penggerak curriculum is, it is very necessary to do an evaluation. This evaluation is to determine the extent to which principals and teachers have mastered the application of the sekolah penggerak curriculum, the sekolah penggerak policy is closely related to the formation of the character of Pancasila students. The evaluation model emerged because of the ongoing effort to measure and human curiosity in applying the principles of evaluation that cover the fields of education, behavior, and the arts. Evaluation always plays an important role in all forms of teaching to produce effective learning (Papadakis, 2018), With evaluation, feedback is obtained which is used to improve materials or teaching methods or to adapt materials to scientific developments (Monroe et al., 2019), so that innovative learning models and teaching scenarios can be produced (Ganefri et al., 2021; Hidayat et al., 2019). The following are the results of the evaluation of the implementation of an innovative learning curriculum in high school in terms of the Context, Input, Process and Product (CIPP) evaluation model, namely:

Evaluation of the Implementation of Innovative Learning Curriculum in High Schools

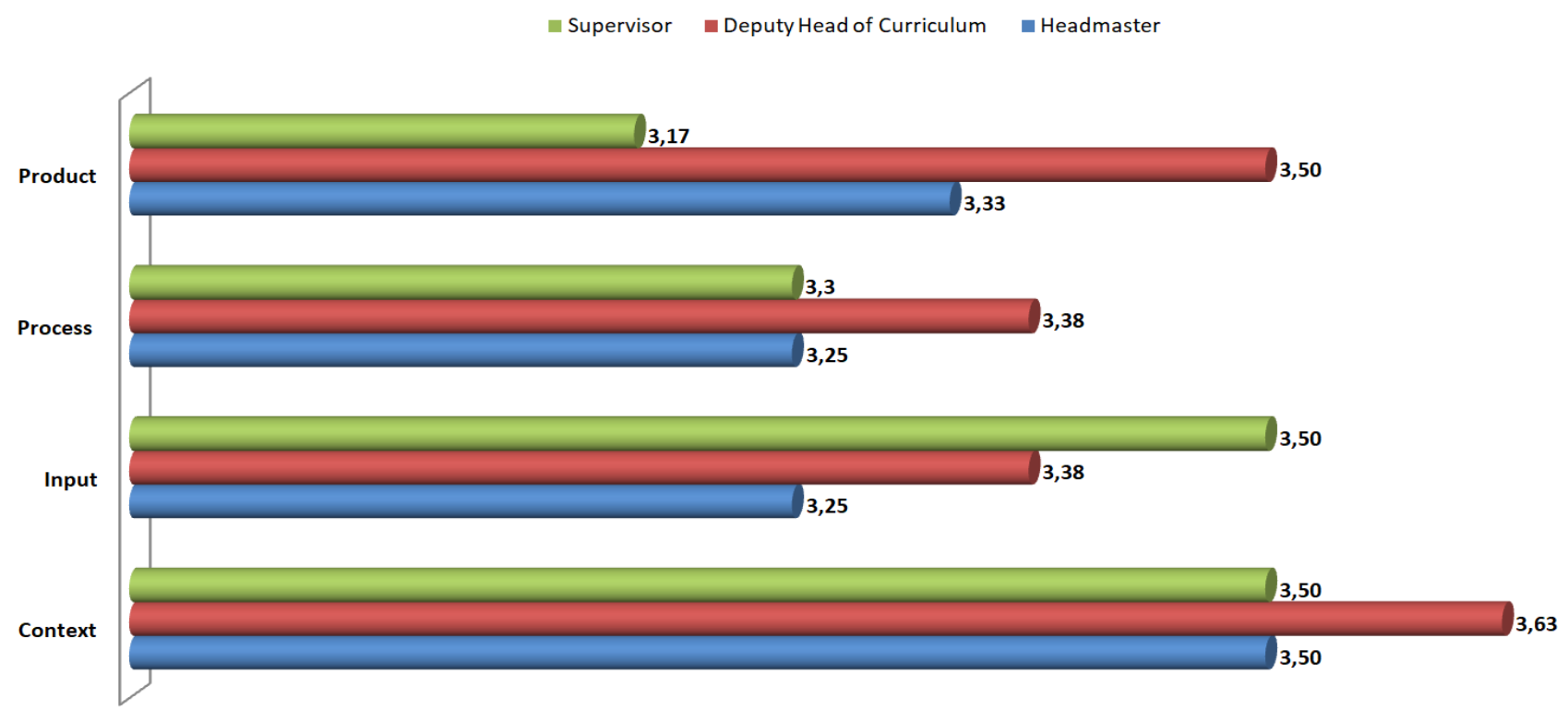

Figure 1. Evaluation results of implementing innovative learning curriculum in high school

Evaluation activities really need to be carried out, especially in seeing and observing the extent to which the new curriculum can be optimally applied in the school environment, not to mention high school in Padang City, from Figure 1 it can be explained as follows, 1) Context component of achievement of sekolah penggerak 
curriculum implementation. In terms of context, the achievement of implementing the sekolah penggerak curriculum in senior high schools with an average score of 3.54 is in the very good category. The curriculum applied in learning is in accordance with student needs, learning objectives and current developments. Principals and teachers in high schools are also very familiar with the concept of learning with the sekolah penggerak curriculum, so that teachers can easily apply it in the classroom and students' interest in learning is increasing because learning is carried out by involving students according to their interests; 2) Component Input achievement of sekolah penggerak curriculum implementation. The achievement of implementing the sekolah penggerak curriculum in terms of input with an average value of 3.38 in the good category. In the designed sekolah penggerak curriculum, the material provided is in accordance with the principles of Pancasila values. The existing facilities and infrastructure are very complete to support the implementation of the sekolah penggerak curriculum. For the perfection of the implementation of the sekolah penggerak curriculum, the principal also supervises and evaluates the implementation of the sekolah penggerak curriculum carried out by teachers in the learning process, which aims to improve the quality and competence of educators. In carrying out learning, the use of the sekolah penggerak curriculum has been effective and the learning strategies used have been adapted to the demands of the sekolah penggerak curriculum; 3) Components The process of achieving the implementation of the sekolah penggerak curriculum. In terms of process, the achievement of implementing the sekolah penggerak curriculum with an average score of 3.29 is in the good category. The level of student understanding of the learning provided is in accordance with the profile of Pancasila students because of the direction and guidance provided by the teacher. The existing facilities and infrastructure in schools, technological developments, and learning media made by teachers are used in learning activities. In evaluating learning, the teacher usesrubricevaluation. Teachers regularly hold improvement briefingscompetence teachers, can be implemented from the special budget of the sekolah penggerak; 4) Component Product achievement of sekolah penggerak curriculum implementation. In terms of product, the achievement of implementing the sekolah penggerak curriculum with an average score of 3.33 is in the good category. The quality of learning outcomes that are expected to be in accordance with the profile of Pancasila students and learning objectives. The implementation of activities, schedules and times that have been designed in the teaching module is carried out well, so that there is an increase in students' abilities and experiences with the learning that has been given.

From the results of the analysis of the observation sheet, it can be seen that the principal, deputy head of the curriculum, supervisors and teachers in high schools already understand the concept of the sekolah penggerak curriculum so that teachers can implement it in the classroom well. The teacher said that students felt more comfortable with the sekolah penggerak curriculum, becauseactivitylearning favors students, namely learning activities that adapt to the learning styles, potentials, and diverse interests of students. Various efforts have been made by teachers so that learning using the sekolah penggerak curriculum can be carried out properly, including adding mastery of new competencies according to the times and technology by learning a lot in order to become teachers who have superior competencies. Furthermore, in addition to the results of the evaluation using the CIPP model, the authors also obtained information related to the comparison of the current conditions of implementing the sekolah penggerak curriculum.

Based on table 2, there are some clearly visible differences between the implementation of the 2013 curriculum and the sekolah penggerak curriculum, especially in the sekolah penggerak curriculum, namely: 1) Improving the quality of learning outcomes; 2) Improving the competence of school principals and teachers; 3) Acceleration of school digitization; 4) Opportunity to become a catalyst for change for other educational units; 5) Accelerating the achievement of the Pancasila student profile; 6) Get intensive assistance; 7) Obtain additional budget for the purchase of books for learning with a new paradigm. The demand to produce quality and competitive graduates is currently very much needed (Hidayat et al., 2019c; Hidayat et al., 2021), so that sekolah penggerak by adopting the principle of digitizing learning are very appropriate (Tasrif et al., 2021).

The sekolah penggerak curriculum is an effort to realize the vision of Indonesian education in realizing an advanced Indonesia that is sovereign, independent, and has personality through the creation of Pancasila Students. The presence of a sekolah penggerak curriculum in schools from the beginning was intended to change the school culture by involving the power of resources from within the school itself and not from external forces. The sekolah penggerak curriculum as a driving force for the transformation of Indonesian education is expected to support student growth and development holistically so that they develop into Pancasila students, become coaches or other teacher mentors for student-centered learning, as well as become role models and transformation agents for the education ecosystem. The implementation of the sekolah penggerak curriculum begins with recruiting teachers, then after that there is education for prospective teacher drivers, and then it is hoped that it will be able to produce a new generation of teacher education leaders who will later become principals, school supervisors, and teacher training instructors. During the training and education period, these prospective teacher movers will be trained on how to lead, trained on their mentorship and their ability to 
make changes in schools, after graduation they will become driving teachers. Furthermore, the educational process and teacher assessment based on the andragogy approach must focus on on the job learning so that it means learning that is relevant, contextual, so that it has the best impact so that the educational process and assessment of this driving teacher is based on impact and evidence. So that we can understand that driving teacher education really creates teachers who are not only good at educating but in the long term this sekolah penggerakcurriculum is an effort to prepare future leaders who will certainly bring changes to the educational ecosystem towards a better direction.

Table 2. Comparison of 2013 Curriculum Implementation and Sekolah penggerak Curriculum

\begin{tabular}{|c|c|c|}
\hline No & $\begin{array}{c}\text { K.13 } \\
2013 \text { Curriculum }\end{array}$ & Education Unit Operational Curriculum \\
\hline 1 & $\begin{array}{l}\text { Curriculum content is in the } \\
\text { center, schools just need to } \\
\text { adjust and copy and paste }\end{array}$ & $\begin{array}{l}\text { It consists of a community of driving teachers, school principals, a } \\
\text { series of activities that they participate in, teacher and student } \\
\text { manuals in the form of teaching modules that are already on the } \\
\text { website of the ministry of education and culture. }\end{array}$ \\
\hline 2 & & $\begin{array}{l}\text { To become a sekolah penggerak, the principal must take a } \\
\text { competency test test. In taking the competency test, it consists of an } \\
\text { essay-shaped academic potential test with level C.6 }\end{array}$ \\
\hline 3 & & $\begin{array}{l}\text { Inviting LPMP to provide materials related to sekolah penggeraks for } \\
\text { teachers through online materials for } 12 \text { days, with an allocation of } \\
2 \text { hours/day. }\end{array}$ \\
\hline 4 & $\begin{array}{l}\text { There is a division of subjects } \\
\text { even though they are wrapped } \\
\text { in a theme }\end{array}$ & $\begin{array}{l}\text { In phase } 10 \text { Subjects, majors are replaced with PAS (IPA: } \\
\text { Chemistry, Physics and Biology } \\
\text { Social Studies : Geography, History, Economics and Sociology). } \\
\text { Class numbering like : } 10 . \text { E.1 }\end{array}$ \\
\hline 5 & Class X.1, XI.1, XII,1 & Phase : 10.E.1, Phase : 11.F.1, Phase 12.F.1 \\
\hline 6 & $\begin{array}{l}\text { Minimum Completeness } \\
\text { Criteria }\end{array}$ & $\begin{array}{l}\text { Criteria for Completeness Learning Objectives } \\
\text { All students pass, pass depending on the criteria: } \\
\text { Criterion 1: } 20 \\
\text { Criterion 2: } 40 \\
\text { Criterion 3: } 60 \\
\text { Criterion 4: } 80 \\
\text { Criterion 5: } 100\end{array}$ \\
\hline \multirow[t]{6}{*}{7} & $\begin{array}{l}\text { Core Competencies and Basic } \\
\text { Competencies }\end{array}$ & $\begin{array}{l}\text { Modules and Learning Outcomes } \\
\text { Learning Outcomes consist of: teaching modules, subject project } \\
\text { modules, collaborative project models } \\
108 \text { hours of lessons/year/ } 1 \text { subjects with a minimum of three } \\
\text { themes, upon graduation being able to write scientific papers. }\end{array}$ \\
\hline & & $\begin{array}{l}\text { Students are grouped based on the results of the academic potential } \\
\text { test whose questions or evaluation tools collaborate with } \\
\text { psychologists }\end{array}$ \\
\hline & & $\begin{array}{l}\text { Students are divided into ability categories, high, medium and low } \\
\text { (unknown by the teacher, only known by the principal and waka). }\end{array}$ \\
\hline & & $\begin{array}{l}\text { In grade } 10 \text { there is a time when students choose teachers and } \\
\text { subjects } \\
\text { Science : Informatics, Mathematics, Chemistry, Physics, Biology } \\
\text { Social Studies:Economics, History, Sociology,Anthropology } \\
\text { Students can choose: } 4 \text { Fields } \\
3 \text { IPA } 1 \text { IPS (medicine) } \\
2 \text { IPA } 2 \text { IPS } \\
3 \text { IPS } 1 \text { IPA } \\
\text { He has entered a directed class according to his talents/aspirations } \\
\text { to be achieved, in collaboration with his parents }\end{array}$ \\
\hline & \multirow[t]{2}{*}{$\begin{array}{l}\text { Workshops during teacher } \\
\text { working groups, leadership } \\
\text { activities }\end{array}$} & $\begin{array}{l}\text { The teacher's request workshop, on the characteristics that he does } \\
\text { not understand, the workshop as a necessity, not a compulsion }\end{array}$ \\
\hline & & $\begin{array}{l}\text { Teachers must be able to arrange questions according to cognitive } \\
\text { level } 1-5 \text {, developed with questions of high order thinking skills }\end{array}$ \\
\hline
\end{tabular}


The debriefing provided during the education of the driving teacher is that the teacher is given an understanding of the paradigm of the sekolah penggerakcurriculum, the driving teacher, and the vision of the driving teacher which includes a reflection of the Indonesian educational philosophy, values, roles, and vision of the driving teacher, as well as an understanding of building culture positive at school. In addition, the sekolah penggerakcurriculum also aims to provide an understanding of pro-student learning practices, and an understanding of learning leaders in school development.

\section{Conclusions}

This study reveals the evaluation of the implementation of the sekolah penggerak curriculum from the context aspect, namely the implementation of the sekolah penggerak curriculum that is in accordance with the needs of students, learning objectives, developments of the times, besides that it has also been seen that the understanding of teachers and school principals is related to the sekolah penggerak curriculum. Furthermore, teachers also have no difficulty in implementing the sekolah penggerak curriculum which has an impact on students' interest in learning for the better, besides that the sekolah penggerak curriculum has also been socialized to stakeholders. In the input aspect, the implementation of learning has fully implemented the sekolah penggerak curriculum as seen from the learning scenarios, learning strategies, there are elements of Pancasila values in learning and infrastructure that support the sekolah penggerak curriculum. Furthermore, in the process aspect, the implementation of the sekolah penggerak curriculum is supported by digital technology facilities in learning, besides that the learning process instills Pancasila values in realizing the profile of Pancasila students. Finally, on the product aspect, in this aspect there has been a match between the learning objectives and the curriculum to be achieved, and this can be seen from the activities and abilities of students in learning, as well as in mastering digital learning technology. So that the harmony between mastery of field competencies and the inculcation of Pancasila values in shaping the profile of Pancasila students can be realized by implementing the sekolah penggerak curriculum.

\section{References}

Afdal, HW, \& Spernes, K. (2018). Designing and redesigning research-based teacher education. Teaching and Teacher Education, 74(1), 215-228.http://dx.doi.org/10.1016/j.tate.2018.05.011

Ahmad, M., \& Nasution, DP (2018). Qualitative Analysis of Students' Mathematical Communication Ability Given Realistic Mathematics Learning. Bushel Journal, 3(2), 8395.https://doi.org/10.31629/jg.v3i2.471

Aquilani, B., Piccarozzi, M., Abbate, T., \& Codini, A. (2020). The role of open innovation and value cocreation in the challenging transition from industry 4.0 to society 5.0: Toward a theoretical framework. Sustainability, 12(21), 8943.https://doi.org/10.3390/su12218943

Aziz, S., Mahmood, M., \& Rehman, Z. (2018). Implementation of CIPP Model for Quality Evaluation at School Level: A Case Study. Journal of Education and Educational Development, 5(1), 189206.https://doi.org/10.22555/JOEED.V5I1.1553

Aziz, A. N., Prastya, D. E., Jubba, H., \& Wahyuni, H. (2021). Evaluasi Kurikulum Pendidikan Agama di Sekolah Dasar Muhammadiyah 001 Sebatik Barat. Ideas: Jurnal Pendidikan, Sosial, dan Budaya, 7(3), 1-10.

Bhakti, Y. (2017). Evaluation of the CIPP Model Program in the Science Learning Process. JIPFRI (Journal of Physics Education Innovation and Scientific Research), $1(2), \quad 75 \quad-$ 82.https://doi.org/10.30599/jipfri.v1i2.109

Black, P., \& William, D. (2018). Classroom assessment and pedagogy. Assessment in education: Principles, policy \& practice, 25(6), 551-575.https://doi.org/10.1080/0969594X.2018.1441807

Dewantara, JA, Efriani, E., Sulistyarini, S., \& Prasetiyo, WH (2020). Optimization of Character Education Through Community Participation Around The School Environment (Case Study in Lab School Junior High School Bandung). JED (Journal of Democratic Ethics), 5(1), 5366.https://doi.org/10.26618/jed.v5i1.33017

Forey, G., \& Cheung, LME (2019). The benefits of explicit teaching of language for curriculum learning in the physical education classroom. English for Specific Purposes, 54, 91109.https://doi.org/10.1016/j.esp.2019.01.001

Fukuda, K. (2020). Science, technology and innovation ecosystem transformation toward society 5.0. International journal of production economics, 220, 107460.https://doi.org/10.1016/j.ijpe.2019.07.033

Ganefri, G., Hidayat, H., Yulastri, A., \& Yondri, S. (2021). The empirical analysis of production-based entrepreneurship training model, readiness and locus of control towards students' entrepreneurship selfefficacy. International Journal of Research in Counseling and Education, 5(1), 5661.https://doi.org/10.24036/00434za0002 
Habibi, M., Jumadi, J., Gummah, S., Ahzan, S., \& Prasetya, DSB (2020). Project brief effects on creative thinking skills among low-ability pre-service physics teachers. int. J. Eval. \& Res. Educ. Vol, 9(2), 415420.http://doi.org/10.11591/ijere.v9i2.20531

Hidayat, H. (2017). How is the Application and Design of a Product-Based Entrepreneurship Learning Tools in Vocational Higher Education?. Advances in Social Science, Education and Humanities Research, volumes 102, 223-228.http://dx.doi.org/10.2991/ictvt-17.2017.38.

Hidayat, H., Herawati, S., Syahmaidi, E., Hidayati, A., \& Ardi, Z. (2018). Designing of technopreneurship scientific learning framework in vocational-based higher education in Indonesia. International Journal of Engineering and Technology(UAE), 7(4), 123-127.https://doi.org/10.14419/ijet.v7i4.9.20632

Hidayat, H., Tamin, BY, Herawati, S., Khairul, K., \& Syahmaidi, E. (2019a). The contribution of technopreneurship scientific learning and learning readiness towards the entrepreneurship learning outcomes in higher vocational education. Journal of Vocational Education, 9(1), 2132.http://dx.doi.org/10.21831/jpv.v9i1.20466

Hidayat, H., Tamin, BY, Herawati, S., Hidayati, A., Muji, AP (2019b). Implementation of technopreneurship scientific learning to produce electronic product prototypes in engineering education. International Journal of Innovative Technology and Exploring Engineering, 8(11), 28422846.http://dx.doi.org/10.35940/ijitee.K2406.0981119

Hidayat, H., Ardi, Z., Yuliana, \& Herawati, S. (2019c). Exploration of the need analysis for technopreneurship scientific learning models in higher vocational education. International Journal of Economics and Business Research, 18(3), 356-368.http://dx.doi.org/10.1504/IJEBR.2019.102733

Hidayat, H., Tasrif, E., Jaya, P., Anwar, M., Hadi, A., Cultural, K., ... \& Asmara, D. (2021). The Empirical Analysis of Industrial Work Challenges in the Industrial Revolution 5.0 Towards a Grade Point Average (GPA) for Electronic Engineering Education Students. International Journal of Online \& Biomedical Engineering, 17(9).https://doi.org/10.3991/ijoe.v17i09.25679

Ma'arif, S. (2018). Education as a Foundation of Humanity: Learning from the Pedagogy of Pesantren in Indonesia . Journal of Social Studies Education Research, 9 (2), 104-123. Retrieved fromhttps://dergipark.org.tr/en/pub/jsser/issue/37944/438286

Maba, W. (2017). Teacher's Perception on the Implementation of the Assessment Process in 2013 Curriculum. International Journal of Social Sciences and Humanities (IJSSH), 1(2), 19.https://doi.org/10.29332/ijssh.v1n2.26

Monroe, MC, Plate, RR, Oxarart, A., Bowers, A., \& Chaves, WA (2019). Identifying effective climate change education strategies: a systematic review of the research. Environmental Education Research, 25(6), 791812.https://doi.org/10.1080/13504622.2017.1360842

Papadakis, S. (2018). Evaluating pre-service teachers' acceptance of mobile devices with regards to their age and gender: a case study in Greece. International Journal of Mobile Learning and Organization, 12(4), 336-352.https://dx.doi.org/10.1504/IJMLO.2018.095130

Purnomo, YHP, \& Santoso, TB (2020). Evaluation of the Selection Program at the "XM" School With the CIPP Evaluation Method. Journal of Economics, Accounting Management and Taxation (Jemap), 3(2), 227-244.https://doi.org/10.24167/jemap.v3i2.2755

Sabri, T. (2017). Value Based Thematics Learning. Journal Of Education, Teaching and Learning, 2(2), $192-$ 196.https://dx.doi.org/10.26737/jetl.v2i2.285

Sibagariang, D., Sihotang, H., \& Murniarti, E. (2021). The Role of Motivating Teachers in Independent Education for Learning in Indonesia. Journal of Educational Dynamics, 14(2), 8899.https://doi.org/10.51212/jdp.v14i2.53

Sulistyo, A. (2017). EVALUATION OF READING CULTURE PROGRAMS IN STATE ELEMENTARY SCHOOL. Manage: Journal of Educational Management, 4(1), 4858.https://doi.org/10.24246/j.jk.2017.v4.i1.p48-58

Supriyantoko, I., Jaya, A., Kurnia, V., \& Habiba, P. G. S. (2020). Evaluasi Implementasi Kebijakan Teaching Factory Dengan Model Evaluasi Cipp Di SMK Negeri DKI Jakarta. Journal of Vocational and Technical Education (JVTE), 2(2), 1-10.

Tasrif, E., Saputra, HK, Kurniadi, D., Hidayat, H., \& Mubai, A. (2021). Designing Website-Based Scholarship Management Application for Teaching of Analytical Hierarchy Process (AHP) in Decision Support Systems (DSS) Subjects. International Journal of Interactive Mobile Technologies, 16(9). https://doi.org/ 10.3991/ijim.v15i09.23513

Umam, KA, \& Saripah, I. (2018). Using the Context, Input, Process and Product (CIPP) Model in the Evaluation of Training Programs. International Journal of Pedagogy and Teacher Education, 2, 19183.https://doi.org/10.20961/ijpte.v2i0.26086

Wijaya, A., Mustofa, MS, \& Husain, F. (2020). Socialization of the Independent Learning Program and Motivating Teachers for Middle School 2 Teachers in Maros Regency. Puruhita Journal, 2(1), 4650.https://journal.unnes.ac.id/sju/index.php/puruhita/article/view/42325/18488. 